\title{
Pemanfaatan Sarana Prasarana dalam Pelaksanaan Bimbingan Konseling di Sekolah
}

\author{
Azmatul Khairiah Sari, Neviyarni, Riska Ahmad, Yarmis Syukur \\ Bimbingan dan Konseling, Universitas Negeri Padang \\ Jl. Prof. Dr. Hamka, Air Tawar Padang, Sumatera Barat \\ E-mail: azmatulkhairiah998@gmail.com
}

\begin{abstract}
Article Info
Abstract

Received Oktober 2021

Accepted November 2021

Published November 2021

Keywords:

Infrastructure, guidance

and counseling

Infrastructure facilities are essentially a support in the implementation of an educational process or the implementation of counseling guidance. Without the infrastructure, the implementation of counseling guidance will be constrained and the goals to be achieved are not as expected. If the infrastructure does not exist in an educational institution, it will cause counseling guidance personnel in schools to have difficulty collaborating in the implementation of counseling guidance in schools. From that counseling guidance requires facilities and infrastructure to be used in the implementation of counseling guidance in schools.

Abstrak : Sarana prasarana pada hakikatnya adalah penunjang dalam pelaksanaan sebuah proses pendidikan atau pelaksanaan bimbingan konseling. Tanpa adanya sarana prasarana maka pelaksanaan bimbingan konseling akan menjadi terkendala dan tujuan yang akan dicapai tidak sesuai dengan yang diharapkan. Apabila sarana prasarana tidak ada dalam sebuah institusi pendidikan maka akan menyebabkan personil bimbingan konseling di sekolah kesulitan dalam berkolaborasi dalam pelaksanaan bimbingan konseling di sekolah. Dari itu bimbingan konseling memerlukan sarana dan prasarana untuk dimanfaatkan dalam pelaksanaan bimbingan konseling di sekolah.
\end{abstract}

Kata Kunci: Sarana Prasarana, Bimbingan konseling

C2021 Jurusan Ilmu Pendidikan, FKIP Universitas Lampung 


\section{PENDAHULUAN}

Sebuah institusi pendidikan diharapkan memiliki sarana prasarana dalam menunjang terlaksananya sebuah proses pembelajaran. Bimbingan konseling sebagai bagian dari institusi pendidikan juga memerlukan adanya sarana prasarana. Diharapkan dengan sarana prasarana maka bimbingan konseling dapat terwujud secara efektif dan efesien. Pihak sekolah yang menjadi personil bimbingan konseling di sekolah pun memiliki tanggung jawab untuk menyediakan, memelihara dan memanfaatkan sarana prasarana di sebuah sekolah (Megasari, 2020).

Tanpa adanya pengelolaan pengaturan sarana prasarana maka akan mustahil sarana prasarana di sebuah sekolah akan tersedia dengan baik. Walaupun tidak tersedia secara keseluruhan namun paling tidak sarana prasarana tersebut ada dan telah diusahakan oleh personil BK di sekolah untuk ada. Sarana prasarana bias dikatakan sebagai sebuah media yang akan memudahkan kinerja kerja seorang guru BK dan juga personil Bk sekolah lainnya dalam menjalankan fungsi layanan bimbingan konseling di sekolah. Setiap personil BK di sekolah memiliki tugas, wewenang, tanggung jawab yang masing-masing harus memahami peran masing-masing (Wardati, dkk, 2011). Maka dari itu segala bentuk sarana prasarana akan dikelola bersama oleh personil BK di sekolah. Dan tentu saja ada pihak yang menyampaikan kebutuhan sarana, ada yang menyediakan dan pada akhirnya memanfaatkan bersama segala bentuk sarana dan prasarana yang ada di sekolah tersebut dalam penyelenggaraan bimbingan konseling di sekolah.

Kita bisa melihat dan membandingkan bagaimana pelaksanaan suatu layanan BK yang difasilitasi dengan adanya sarana serta prasarana dengan layanan bimbingan konseling yang tidak diberikan falisilitas dalam bentuk sarana prasarana. Jika bisa memilih tentu personil BK di sekolah dan guru BK akan lebih aman dengan fasilitas sarana prasarana yang diberikan sekolah tersebut. Sarana dan prasarana sebagai dinamika penggerak yang akan memobilisasi pelaksanaan kegiatan layanan BK khusunya di sekolah (Sugiarto, 2021). Layanan bimbingan konseling akan bergerak dengan laju seimbang apabila didukung oleh fasilitas yang memadai. Namun apabila fasilitas yang ada minim maka bisa jadi pelaksanaan bimbingan konseling akan terkendala 
dan jalannya akan melambat. Begitu pentingnya sebuah sarana prasarana dalam bimbingan konseling.

Dalam sebuah institusi pendidikan yang biasa kita kenal dengan sekolah, maka diperlukan adanya pengelolaan sarana prasarana yang tepat agar bisa mengetahui hal apa saja yang berkaitan dengan sarana prasarana yang diperlukan dan yang tersedia agar kegiatan pendidikan yang direncanakan dapat berlangsung dengan baik dan lancar tanpa terkendala apapun. Disebutkan juga dalam Peraturan Menteri Pendidikan Nasional Republik Indonesia No 24 Tahun 2007 bagaimana Sarana dan Prasarana di Instansi pendidikan. Dalam peraturan ini menegaskan pada masing-masing institusi pendidikan diwajibkan untuk menganggarkan dan melengkapi pelaksanaan pendidikan dengan sarana dan prasarana. Adapun sarana dan prasarana yang dimaksud seperti perabotan yang dapat menunjang terlaksananya proses pendidikan, selanjutnya peralatan pendidikan, menyediakan media yang digunakan dalam pendidikan, buku dan sumber yang digunakan dalam proses pendidikan, bahan yang langsung habis pakai, serta hal lain yang menyangkut dengan sarana prasarana yang menunjang terjadinya proses pendidikan dalam institusi pendidikan tersebut. Sehingga proses pendidikan terjadi secara berkesinambungan dan lancar.

Pada sebuah sekolah, prasarana yang diwajibkan untuk diadakan adalah lahan tempat proses pendidikan berlangsung, ruang kelas yang emmadai dengan jumlah siswa yanga da di sekolah tersebut, ruang pimpinan pada sekolah tersebut, ruang majelis guru atau pendidik pada sekolah tersebut. Hal lainnya yang harus ada adalah ruang tata usaha yang berkaitan dengan administrasi sebiah sekolah, ruang pustaka untuk mencari referensi penunjang proses pendidikan, ruang laboratorium, ruang kantin sebagai tempat penunjang kebutuhan fisik dari personil BK sekolah. Ruang bengkel kerja sebagai wadah praktek bagi siswa, instalasi daya dan jasa, tempat berolahraga yang memadai dengan jumlah siswa yang terdaftar di sekolah tersebut, tempat beribadah sesuai dengan agama yang dianut oleh personil BK di sekolah tersebut, tempat bermain, tempat berkreasi, dan ruang/tempat lain yang diperlukan untuk medukung terjadiny sebuah proses pendidikan secara komprehensif dan teratur dan dalam pengadaan sarana prasarana tersebut juga memerlukan evaluasi (Manurung, dkk, 2020). Untuk melihat bagaimana kondisi sarana prasarana 
yang dimiliki dan sejauh mana telah memberikan manfaat untuk pelaksanaan proses pendidikan atau layanan bimbingan konseling di sekolah.

Pengelolaan sarana prasarana dalam sebuah sekolah harus diperjelas dan dijelaskan siapa saja yang bertanggung jawab dalam pengelolaan sarana prasarana tersebut. Tanpa adanya pengelolaan yang jelas maka akan menyebabkan sarana prasarana dalam sebuah sekolah menjadi terkatungkatung dan tidak menentu. Hal ini akan menyebabkan sarana prasarana di sebuah sekolah tidak mengalami perbaikan dan peremajaan. Dari hasil penelitian menunjukkan baru 50\% instansi pendidikan yang menyediakan dan memfasilitasi sekolah tersebut dengan sarana prasarana yang cukup dan searah dengan ketentuan seharusnya mengenai ruangan bimbingan konseling di Permendikbud No. 111 Tahun 2014 (Putranti, 2015). Sementara ketersediaan sarana prasarana akan menunjang terselenggaranya kegiatan layanan bimbingan konseling di sekolah dengan berkesinambungan dan terarah apabila sistem yang ada di sekolah memang memperhatikan tercukupinya sarana prasarana BK di sekolah tersebut (Schmidt, 2010). Dukungan sekolah dengan sama-sama saling bekerja sama dalam pengelolaan sarana prasarana sangat diharapkan sekali untuk terciptanya kondisi yang kondusif untuk pelaksanaan layanan bimbingan konseling.

Selain itu kepala sekolah yang menjadi pimpinan sebuah sekolah memiliki andil yang cukup besar dengan menyampaikan kebijakan yang memihak pada pelaksanaan bimbingan konseling di sekolah. Salah satunya adalah penyediaan sarana prasarana yang mencukupi untuk terselenggaranya bimbingan konseling di sekolah yang ia pimpin (Ludin, 2013). Dan nantinya kepala sekolah yang menjadi bagian dari personil BK di sebuah sekolah akan menyampaikan kebijakan yang ia buat untuk dijalnkan bersama oleh personil Bk sekolah yang brerada dibawah kepemimpinannya.

Sarana prasarana dalam pelaksanaan bimbingan konseling diharapkan dapat menjadikan subjek layanan yaitu siswa dapat merasakan sendiri betapa menyenangkannya sebuah layanan bimbingan konseling. Dan guru BK yang menajdi pelaksana utama dalam layanan bimbingan konseling dapat dengan mudah mencapai hasil yang diharapkan dari sebuah layanan tersebut. Ketersediaan sarana prasarana BK di sebuah sekolah akan sejalan dengan 
keberhasilan yang akan diraih oleh personil BK di sekolah dalam hal pencapaian tujuan bimbingan konseling (Bhakti, 2017).

Sarana prasarana yang ada di sebuah sekolah harus dimanfaatkan dengan sebaiknya oleh personil BK di sekolah untuk menjadikan layanan bimbingan konseling yang efektif dan efesien. Sasaran dalam pelaksanaan layan bimbingan dan konseling mencerminkan bagaimana keahlian dan keterampilan guru BK (Lubis, 2011). Apabila seorang guru BK ahli dan terampil ia akan menggunakan format politik untuk menyediakan sarana prasana layanan bimbingan konseling di sekolah tersebut.

\section{METODE}

\section{Jenis Penelitian}

Penelitian ini merupakan penelitian kualitatif, dan yang akan dibahas adalah sesuai dengan topik kajian. Maka jenis penelitian ini termasuk dalam kategori penelitian kepustakaan (library research).

\section{Teknik Pengumpulan Data}

Berdasarkan studi literatur pada tinjauan pustaka maka yang akan jadi topik bahasannya adalah konsep sarana dan prasarana BK dan pengelolaan sarana prasraana BK di institusi pendidikan atau sekolah.. Jenis data yang digunakan adalah data sekunder. Metode pengumpulan data adalah studi pustaka, yang digunakan untuk pengkajian studi literatur yang telah dikumpulkan.

\section{Teknik Analisis Data}

Data yang diperoleh dikompulasi, dianalisis, dan disimpulkan sehingga mendapatkan kesimpulan mengenai studi literatur. Sehingga pada akhirnya nanti akan tampaklah suatu kesimpulan bagaimana sarana prasarana BK di sebuah sekolah dan pemanfaatan sarana prasarana BK di sebuah sekolah. 


\section{HASIL DAN PEMBAHASAN}

Sarana prasarana dalam BK adalah sesuatu hal yang mesti dipersiapkan oleh pihak sekolah. Hal ini dilakukan dikarenakan untuk menunjang terjadinya pelaksanaan bimbingan konseling yang efektif dan efesien. Terlepas dari hal itu, sarana dan prasarana juga sudah dijelaskan dalam peraturan Menteri harus disediakan dalam sebuah lembaga formal yaitu sekolah.

Kita harus mengetahui konsep mengenai sarana dan prasarana dalam layanan bimbingan konseling. Sarana pendidikan yaitu keseluruhan perangkat dan dalam bentuk alat-alat, bahan material, dan perabotan yang langsung dapat dimanfaatkan dalam proses pendidikan di sekolah. Dan prasarana adalah keseluruhan perlengkapan dasar yang tidak secara langsung memberikan fasilitas untuk terlaksananya proses pendidikan (Daryanto, 2001). Dikatakan bahwa sarana dan prasarana yang terkadang disamakan saja oleh beberapa orang ternyata memiliki konsep yang berbeda. Sarana adalah semua bentuk penunjang dalam pelaksanaan bimbingan konseling yang dapat memberikan manfaat secara langsung. Ketika melaksanakan layanan konseling perorangan oleh guru BK kepada siswa, siswa duduk diatas kursi konseling perorangan maka itu dinamakan sarana karena memberikan manfaat secara langsung. Sementara ketika layanan konseling perorangan diadakan di ruang konseling yang nyaman dan sesuai dengan standar seharusnya maka itu adalah prasarana.

Begitu pentingnya penyediaan sarana prasarana dalam proses pendidikan, akan menentukan bagaimana hasil dari pendidikan tersebut (Novita, 2017). Begitu juga pelaksanaan layanan bimbingan konseling yang juga merupakan proses pendidikan. Akan gagal layanan bimbingan konseling apabila tidak difasilitasi oleh sarana dan prasarana. Bagaimana guru BK bisa mengetahui apa kebutuhan siswa asuhnya apabila sarana dalam bentuk instrumen tidak disediakan oleh pihak sekolah. Bagaimana layanan konseling perorangan bisa berjalan lancar apabila ruangan konseling perorangan yang harusnya bersifat privacy namun tidak disediakan pihak sekolah. Maka dari itu sarana prasarana harus diperhatikan oleh pihak sekolah.

Klasifikasi sarana yang dapat dimanfaatkan dalam proses pendidikan dapat dilihat dari segi (Mufadhal, 2003): 
a. Habis tidaknya dipakai dalam pelaksanaan pendidikan. Ketika pelaksanaan pendidikan atau pemberian layanan bimbingan konseling, ada dua jenis sarana yang langsung habis dipakai ketika pelaksanaan layanan bimbingan konseling atau yang tidak langsung habis dipakai:

Sarana yang langsung habis dipakai. Ada jenis sarana yang langsung habis dalam waktu singkat ketika pemberian layanan bimbingan konseling. Seperti pena untuk mencatat kemajuan siswa setelah pelaksanaan layanan bimbingan konseling, kertas yang tidak bisa diduar ulang ketika sudah ditulis oleh siswa setelah layanan informasi berlangsung. Sarana yang tahan lama dan tidak langsung habis pakai selama proses pendidikan atau pemberian layanan bimbingan konseling. Seperti kursi yang dijadikan tempat duduk oleh siswa dalam layanan bimbingan konseling, meja yang dipakai guru BK dalam pemberian layanan informasi dan masih banyak lainnya.

b. Bergerak Tidaknya Pada Saat Digunakan. Sarana dalam proses pendidikan atau layanan bimbingan konseling memiliki dua jenis bagian apabila dilihat dari segi bergerak atau tidaknya saat digunakan dalam proses layanan bimbingan konseling:

Sarana yang bisa digerakkan saat proses pendidikan atau layanan bimbingan konseling. Bisa dicontohkan seperti buku kasus siswa, map mengenai data siswa, instrumen yang digunakan untuk mengungkapkan masalah siswa, dan lain sebagainya. Sarana yang tidak bergerak saat digunakan pada saat proses pendidikan atau layanan bimbingan konseling. Misalnya saja ruangan konseling perorangan yang memiliki atap untuk menghindari siswa dan guru BK kehujanan saat layanan konseling perorangan. Akan sulit untuk memindahkan atap tersebut walaupun itu bisa saja dilakukan.

c. Hubungannya dengan Proses Belajar Mengajar atau dalam proses layanan bimbingan konseling. Dari segi ini ada dua jenis sarana tersebut, yaitu Sarana yang langsung digunakan untuk layanan bimbingan konseling. Bisa dicontohkan seperti kertas koran untuk mengetahui masalah yang dialami siswa melalui gambar, lembar jawaban siswa dalam mencari tahu kebutuhan siswa, dan sebagainya. Sarana yang tidak secara langsung digunakan dalam 
proses layanan bimbingan konseling. Bisa kita contohkan seperti lemari penyimpanan data siswa.

Adapun prasarana di dalam proses pendidikan atau pelaksanaan layanan bimbingan konseling dapat dibagi dalam dua bagian, yaitu:

a. Prasarana yang langsung digunakan dalam proses pendidikan atau pelaksanaan layanan bimbingan konseling. Bisa dicontohkan seperti ruang konseling perorangan, ruangan konseling kelompok, ruang guru BK, dan lain sebagainya.

b. Prasarana dalam proses pendidikan atau pelaksanaan layanan bimbingan konseling yang keberadaannya tidak digunakan sevara langsung untuk terlaksananya proses pendidikan atau pelaksanaan layanan bimbingan konseling. Namun prasarana tersebut mendukung terjadinya proses pendidikan atau pelaksanaan layanan bimbingan konseling. Dicontohkan seperti ruangan kepala sekolah, ruangan guru mata pelajaran, ruangan kantin sekolah, ruangan perpustakaan, dan lain sebagainya.

Sarana prasarana akan dikelola oleh personil BK di sekolah. Oleh karena itu masing-masing personil BK sekolah harus memahami beberapa prisnip yang harus ditaati dalam pengelolaan sarana prasarana tersebut. Adapun prinsip yang harus diperhatikan dalam pengelolaan sarana prasarana BK (Matin, 2016):

a. Prinsip pencapaian tujuan. Dalam pengelolaan sarana prasarana yang ada di sekolah diharapkan seluruh sarana prasarana bisa mengantarkan pada tujuan proses pendidikan atau layanan bimbingan konseling yang diinginkan. Apabila guru BK menginginkan tujuan dari layanan bimbingan konseling adalah siswa memahami dirinya dan masalah yang ia hadapi dan ini bersifat rahasia maka diharapkan sarana dan prasarana yang ada di sekolah tersebut bisa menjadi pendukung untuk pencapaian tujuan tersebut. Sarana dan prasarana yang ada di sekolah haruslah siap saat guru BK atau personil BK sekolah ingin menggunakannya dalam layanan bimbingan konseling tersebut. Karena ketika ia dibutuhkan dan sarana dan prasarana langsung ada maka tujuan yang ingin dicapai akan lebih mudah untuk menjangkaunya.

b. Prinsip efesiensi. Sarana dan prasarana bimbingan konseling yang ada di sekolah merupakan fasilitas yang harus dijaga oleh seluruh pesonil BK di 
sekolah. Mendapatkan sarana dan prasarana tersebut tidaklah gampang. Sehingga ketika sarana prasarana telah diberikan menjadi kewajiban bersama untuk menjaga dan memelihara sehingga bisa dimanfaatkan untuk pelayanan bimbingan konseling. Dengan memanfaatkan sarana prasarana bimbingan konseling diharapkan dapat mengurangi pemborosan dana sekolah.

c. Prinsip administratif. Administratif berarti pengelolaan sarana prasarana BK, pemanfaatan sarana prasarana BK harus memperhatikan ketentuan yang ditetapkan di sekolah tersebut. Apabila hendak memakai ruangan BK maka harus dipakai untuk pelaksanaan layanan bimbingan konseling. Dan pemakaian sarana prasarana BK juga memiliki aturan dan pedoman dalam pemanfaatannya.

d. Prinsip kejelasan tanggung jawab. Personil BK di sekolah memiliki tanggung jawab masing-masing. Berkaitan dengan pengelolaan sarana dan prasarana $\mathrm{BK}$, personil BK juga harus memiliki kejelasan mengenai tanggung jawab pengelolaan sarana dan prasarana tersebut. Harus jelas siapa yang merumuskan sarana dan prasarana apa yang dibutuhkan dalam layanan bimbingan konseling, siapa personil BK di sekolah yang menyediakan sarana dan prasarana BK, dan siapa yang merumuskan biaya anggaran sarana dan prasarana BK di sekolah.

e. Prinsip kekohesifan. Sarana dan prasarana yang ada merupakan fasilitas yang harus sama-sama dijaga dan dipelihara oleh personil BK di sekolah. Tersedianya sarana dan prasarana yang minim pun harus bisa dimanfaatkan sebaik mungkin oleh personil BK di sekolah. Pengelolaan sarana prasarana BK merupakan bentuk perwujudan manajemen dalam struktur organisasi personil BK di sekolah dan bukti kompaknya personil BK di sekolah. Adanya kekompakan dan rasa solidaritas personil BK di sekolah terwujud dengan pengelolaan dan pemanfaatan sarana prasarana BK di sekolah.

Manajemen pengelolaan sarana prasarana BK di sekolah tidak terlepas dari dimulainya perencanaan mengenai penyediaan sarana dan prasarana untuk pelaksanaan layanan bimbingan konseling. Dalam perencanaan, tentu masing-masing personil harus memahami prinsip dasar perencanaan sarana dan prasarana BK di sekolah (Mufadhal, 2003), diantaranya : 
a. Dalam merencanakan sarana dan prasarana BK di sekolah harus benarbenar hasil dari proses intelektual. Para pesonil BK di sekolah benar-benar harus memikirkan apakah sarana dan parasarana tersebut memang dibutuhkan di sekolah dan melancarkan terlaksananya bimbingan konseling di sekolah. Dan harus juga memikirkan apakah sarana prasarana tersebut memang benar-benar untuk mencerdaskan siswa di sekolah tersebut. Penyediaan wifi di sekolah misalnya. Harus melewati proses intelektual dari para personil BK di sekolah, apakah benar-benar menguntungkan bagi siswa di sekolah dan mendukung pelayanan bimbingan konseling. Kalau banyak dimanfaatkan untuk sekedar game online oleh siswa tentu hal ini tidak melalui proses inetelektual sebelumnya oleh personil BK di sekolah.

b. Merencanakan pengadaan sarana dan prasarana BK berdasarkan analisis kebutuhan. Apabila wifi diadakan di sekolah untuk membantu guru BK dalam pemberian layanan bimbingan konseling secara daring, tentu hal ini merupakan kebutuhan saat ini yang memang dituntut untuk telaten dengan tekhnologi. Menyediakan kertas koran karena dianggap sebagai media dalam layanan konseling perorangan dan itu memudahkan layanan bimbingan konseling. Ini merupakan suatu kebutuhan yang diusahakan harus sebagai pertimbangan atas analisis kebutuhan dari sasaran layanan bimbingan konseling.

c. Merencanakan sarana dan prasarana harus dengan realistis dan tidak mengada-ada. Dikarenakan penganggaran dana sarana prasarana dilakukan pada awal semester berlangsung, maka personil BK di sekolah harus membuat anggran yang tidak berlebihan misalnya pembelian 10 kursi untuk bimbingan kelompok, kemudian dianggarkan dengan dana 10 juta rupiah. Hal ini tidak realistis dan tidak sesuai dengan kenyataan. Maka anggaran untuk sarana prasarana dibuatkan dalam bentuk yang rasional.

d. Sarana dan prasarana harus dijelaskan dalam bentuk, merek, jumlah, jenis dan rincian yang detail. Hal ini dilakukan untuk transparansi dana dan sebagai bentuk pertanggungjawaban personil BK yang memang bertanggung jawab dalam pengelolaan dan pemanfaatan sarana dan prasarana BK di sekolah. 
Dalam pemanfaatan sarana dan prasarana bimbingan konseling, seorang personil Bk di sekolah harus memahami bahwa sarana dan prasarana adalah hal yang harus dipelihara. Namun tidak jarang, setelah melalui perawatan yang cukup baik dan lama namun terkadang sarana dan prasarana tersebut rusak atau kurang maksimal untuk dimanfaatkan dalam pelayanan bimbingan konseling. Dan untuk pengadaan kembali sarana dan prasarana ke pihak pimpinan tentu memiliki alur tersendiri.

Sarana prasarana secara umum dapat direncanakan untuk dihapuskan pengadaannya apabila memenuhi kriteria. Kriteria yang harus dipenuhi adalah (Syahril, 2004):

a. Sarana dan prasarana yang ada di sekolah tersebut dalam keadaan yang sudah rusak. Kerusakan tersebut tergolong pada kerusakan berat dan tidak bisa diperbaiki. Dan pada akhirnya kerusakan tersebut mengakibatkan sarana dan prasarana tersebut tidak dapat dimanfaatkan dalam proses pendidikan atau proses layanan bimbingan konseling di sekolah. Apabila kursi layanan konseling perorangan sudah patah, kemudian tidak bisa diperbaiki lagi maka manfaat yang didapatkan dari sarana dan prasarana itu tidak akan bisa diambil. Untuk itu kursi harus dihapuskan dari data sarana prasarana di sekolah yang terdaftar.

b. Sarana prasarana BK yang rusak dan kurang maksimal untuk dimanfaatkan dalam layanan bimbingan konseling, apabila diperbaiki akan memakan anggaran dana yang cukup besar. Maka akan dipilih opsi untuk menghapus sarana dan prasarana BK dari daftar yang ada di bagian adminitrasi sekolah tersebut.

c. Apabila sarana dan prasarana yang pemanfaatannya lebih besar daripada biaya pemeliharaannya. Dalam memanfaatkan sarana dan prasarana tersebut memakan biaya yang cukup besar, maka biasanya kebijakan yang dilakukan pimpinan sebuah sekolah adalah penghapusan data sarana prasarana tersebut. Di sebuah sekolah harus mengupayakan hematnya anggaran dana sekolah dibandingkan menghamburkannya atas dasar pemanfaatan sarana dan prasarana BK tersebut.

d. Sarana dan prasarana yang tidak sesuai dengan tuntutan kebutuhan zaman sekarang, atau masa kini atau bisa dikatakan sudah ketinggalan zaman. Maka personil BK sekolah akan merumuskan untuk pengadaan sarana dan 
prasarana BK untuk dapat dimanfaatkan dalam layanan bimbingan konseling. Dan menghapus sarana prasarana yang tidak sesuai dengan kebutuhan sekolah. Kita contohkan apabila instrumen yang dipakai tidak lagi dapat mengukur keadaan kekinian dari siswa asuh maka guru BK dapat mengusulkan untuk pengadaan instrumen baru yang sesuai dengan permasalahan siswa saat sekarang. Tentu tidak lepas dari anggran dana yang harus diperhitungkan oleh personil BK sekolah lainnya. Sementara instrumen yang lama akan dihapuskan dari daftar sarana prasarana BK yang dimiliki sekolah tersebut.

e. Apabila sarana dan prasarana yang dimiliki melebihi kapasitas dan apabila tidak dimanfaatkan akan menimbulkan kerugian yang besar. Misal infocus yang dimiliki oleh sebuah sekolah berlebih namun apabila tidak dimanfaatkan akan membuat infocus rusak. Maka hal ini juga harus dikelola dengan tepat dan bijak oleh personil BK sekolah agar tidak menimbulkan kerugian bagi sekolah tersebut.

Penghapusan sarana dan prasarana BK di sebuah sekolah memiliki tujuan tertentu. Tujuan dihapuskannya sarana dan prasarana BK tersebut adalah membebaskan bendaharawan barang atau pengelola sarana prasarana BK sekolah dari pertanggung jawaban administrasi dan fisik atas barang milik negara yang pengurusannya sesuai dengan ketentuan perundanganperundangan yang berlaku.

Adapun bentuk sarana dalam pelaksanaan layanan bimbingan konseling dapat kita lihat seperti (Sukardi, 2000):

a. Alat pengumpul data. Data diperlukan untuk pertimbangan bagi guru BK dalam pemberian layanan bimbingan konseling yang sesuai untuk siswanya. Alat pengumpul data penting diadakan di sebuah sekolah demi terlaksananya layanan bimbingan konseling di sekolah. Adapun alat pengumpul data tersebut meiluti format, pedoman observasi, pedoman wawancara dengan siswa, angket, catatan harian, daftar nilai prestasi belajar, kartu konsultasi, instrumen penelusuran bakat dan minat, serta alat pengumpul data lainnya. 
b. Alat penyimpan data. Data yang dikumpulkan dari siswa memerlukan privacy, dimana siswa memerlukan adanya perlindungan terhadapat data pribadi yang ia miliki. Alat penyimpan data seperti kartu pribadi, buku pribadi, map dan sebagainya.

c. Perlengkapan teknis. Dalam pelaksanaan layanan bimbingan konseling di sekolah memerlukan perlengkapan teknis penyelenggaraan layanan bimbingan konseling. Perlengkapan teknis yang dimaksud seperti buku pedoman pelaksanaan layanan $\mathrm{BK}$, buku informasi, alat tulis, dan sebagainya.

Sarana merupakan fasilitas yang secara langsung memberi manfaat kepada onjek sasaran layanan dan juga pemberi layanan. Tanpa sarana maka tidak ada manfaat yang didapatkan dari pelaksanaan layanan bimbingan konseling.

Adapun prasarana BK yang dapat dimanfaatkan selama pelaksanaan layanan BK adalah seperti berikut:

a. Ruang bimbingan. Ruangan bimbingan dimanfaatkan dalam pelaksanaan layanan bimbingan konseling oleh guru BK. Pada ruangan bimbingan terdiri dari ruang tamu, ruang konsultasi, ruangan pelaksanaan bimbingan kelompok, ruang dokumentasi dan sebagainya. Diharapkan dalam ruangan bimbingan juga difasilitasi dengan perabotan seperti meja, kursi, lemari, papan tulis, dan sebagainya.

b. Anggaran biaya. Adanya anggaran biaya untuk mendukung terlaksananya layanan bimbingan konseling di sebuah sekolah. Tanpa adanya anggaran biaya maka mustahil pelaksanaan layanan bimbingan konseling bisa efektif dan efesien. Anggaran biaya untuk pengadaan fasilitas, anggaran biaya untuk pemeliharaan, dan juga termasuk anggaran biaya perbaikan atau pergantian fasilitas yang ada.

Sarana prasarana yang ada di sebuah sekolah harus dimanfaatkan dalam mensukseskan terjadinya layanan bimbingan konseling di sekolah. Pada akhirnya bimbingan konseling menjadi sesuatu yang sangat disenangi banyak pihak karena didukung dengan tersedianya sarana dan prasarana yang memadai. 


\section{KESIMPULAN}

Sarana dan prasarana merupakan suatu keharusan dalam sebuah sekolah. Maka dari itu pihak sekolah harus mengelola sarana prasarana dengan tepat agar sarana dan prasarana dapat dimanfaatkan dengan baik oleh pihak sekolah. Guru BK juga begitu, sarana prasarana yang ada di sekolah harus dimanfaatkan dengan baik dan tepat. Sehingga pelaksanaan bimbingan konseling dapat mencapai tujuan yang diharapkan. Guru bimbingan konseling dapat dengan mudah memberikan layanan BK sementara siswa yang menjadi sasaran layanan BK dapat merasa bahwa dia adalah individu yang penting dan merasa nyaman dengan layanan BK yang diberikan oleh guru tersebut.

\section{DAFTAR PUSTAKA}

Bhakti, C. P. (2017). Ketersediaan Sarana Dan Prasarana Bimbingan Dan Konseling Di Sekolah Menengah Di Kabupaten Gunungkidul. JP (Jurnal Pendidikan): Teori dan Praktik, 2(2), 100-104.

Daryanto, H.M. (2001). Administrasi Pendidikan. Jakarta: Rineke Cipta.

Lubis, Namora Lumongga. (2011). Memahami Dasar-Dasar Konseling Dalam Teori Dan Praktek. Jakarta: Kencana.

Luddin, A. B. M. (2013). Kinerja kepala sekolah dalam kegiatan bimbingan dan konseling. Jurnal Ilmu Pendidikan, 19(2).

Manurung, R., Harahap, E., Tahrun, T., \& Suharyadi, A. (2020). Manajemen Sarana Prasarana di Sekolah Dasar Negeri 1 Kota Prabumulih. Jurnal Manajemen Pendidikan: Jurnal Ilmiah Administrasi, Manajemen dan Kepemimpinan Pendidikan, 2(2), 168-177.

Matin \& Nurhattati Fuad. (2016). Manajemen Sarana dan Prasarana: Konsep dan Aplikasinya. Jakarta: PT. Rajagrafindo.

Megasari, R. (2020). Peningkatan pengelolaan sarana dan prasarana pendidikan untuk meningkatan kualitas pembelajaran di SMPN 5 Bukittinggi. Jurnal Bahana Manajemen Pendidikan, 2(1), 636-648.

Mufadhal, Ibrahim. (2003). Seri Manajemen Peningkatan Mutu Pendidikan Berbasis Sekolah Manajemen Perlengkapan Sekolah Teori dan Aplikasinya. Jakarta: PT Bumi Aksara.

Novita, M. (2017). Sarana dan prasarana yang baik menjadi bagian ujung tombak keberhasilan lembaga pendidikan islam. Nur El-Islam, 4(2), 97129.

Putranti, D. (2015). Studi Deskriptif Tentang Sarana dan Prasarana Bimbingan dan Konseling di Sekolah Menengah Pertama. PSIKOPEDAGOGIA Jurnal Bimbingan dan Konseling, 4(1), 45-50.

Schmidt, J.J., (2010). The Elementary/Middle School Counselor Survival Guide Third Edition, Boston: John Wiley \& Sons. 
Sugiarto, S., Neviyarni, S., \& Firman, F. (2021). Peran Penting Sarana dan Prasarana Dalam Pembelajaran Bimbingan Konseling di Sekolah. JPT: Jurnal Pendidikan Tematik, 2(1), 60-66.

Sukardi, Dewa Ketut. (2000). Pengantar Pelaksanaan Program Bimbingan dan Konseling di Sekolah. Jakarta: Rineka Cipta.

Syahril. (2004). Manajemen Sarana dan Prasarana Pendidikan. Padang : Jurusan Administrasi Pendidikan UNP.

Wardati dan Mohammad Jauhar. (2011). Implementasi Bimbingan dan Konseling Di Sekolah. Jakarta: Prestasi Pustaka. 